University of South Carolina

Scholar Commons

\title{
Influence of Some Design Variables on the Thermal Behavior of a Lithium-Ion Cell
}

Gerardine G. Botte

Bradley A. Johnson

Ralph E. White

University of South Carolina - Columbia,white@cec.sc.edu

Follow this and additional works at: https://scholarcommons.sc.edu/eche_facpub

Part of the Chemical Engineering Commons

\section{Publication Info}

Published in Journal of the Electrochemical Society, Volume 146, Issue 3, 1999, pages 914-923.

(c) The Electrochemical Society, Inc. 1999. All rights reserved. Except as provided under U.S. copyright law, this work may not be reproduced, resold, distributed, or modified without the express permission of The Electrochemical Society (ECS). The archival version of this work was published in Botte, G.G., Johnson, B.A., \& White, R.E. (1999). Influence of Some Design Variables on the Thermal Behavior of a Lithium-Ion Cell. Journal of the Electrochemical Society, 146(3) 914-923.

Publisher's Version: http://dx.doi.org/10.1149/1.1391700

This Article is brought to you by the Chemical Engineering, Department of at Scholar Commons. It has been accepted for inclusion in Faculty Publications by an authorized administrator of Scholar Commons. For more information, please contact digres@mailbox.sc.edu. 


\title{
Influence of Some Design Variables on the Thermal Behavior of a Lithium-Ion Cell
}

\author{
Gerardine G. Botte, * Bradley A. Johnson,* and Ralph E. White** \\ Center for Electrochemical Engineering, Department of Chemical Engineering, University of South Carolina, Columbia, South \\ Carolina 29208, USA
}

\begin{abstract}
A mathematical model that includes an anode (carbon) decomposition reaction has been used to predict the temperature of a lithium-ion cell during medium- and high-rate discharge conditions. This work describes how various design parameters and the activation energy for the decomposition reaction of the anode (carbon) affect the predicted temperature of a $\mathrm{Li}_{x} \mathrm{C}_{6} / \mathrm{Li}_{y} \mathrm{NiO}_{2}$ cell. The predicted results show that the particle size in the negative electrode (assumed here to be petroleum coke) is an important parameter for predicting the temperature of the cell.
\end{abstract}

(C) 1999 The Electrochemical Society. S0013-4651(98)05-051-4. All rights reserved.

Manuscript submitted May 18, 1998; revised manuscript received November 25, 1998.

The occurrence of several safety incidents in secondary lithium and lithium-ion batteries prompted this work. For example, the first of these incidents occurred in 1988 for a secondary lithium battery system when several $\mathrm{Li} / \mathrm{Li}_{y} \mathrm{MoS}_{2}$ cells produced by Moli had incidents of flaming in cellular phone applications in Japan. ${ }^{1}$ Another safety incident occurred with lithium-ion batteries at Apple in $1995 .{ }^{2}$ This incident occurred in-house during the testing of newly manufactured PowerBook 5300 portable computers. It was determined that the incident was caused when a lithium-ion cell was overcharged, which caused pressure buildup and venting. Apple subsequently removed all lithium-ion battery packs from their product lines. ${ }^{3}$ Also, Ericsson announced that its mobile phones and other portable electronic applications would not use the lithium-ion battery. ${ }^{4}$ These incidents highlight the importance of safety in commercial lithium-ion applications.

Mathematical modeling has been used by several workers to study thermal management in batteries. For example, Evans and White ${ }^{5}$ examined thermal runaway in a $\mathrm{Li} / \mathrm{SOCl}_{2}$ system by assuming a localized random hot spot near the center of a spiral cell. Evans and White's work focused on predicting thermal profiles and examining conduction of heat out of the cell. Chen and Evans ${ }^{6}$ examined the impact of a single short-circuited cell on the cell stack of a lithium-ion battery. Chen and Evans show results of the cell stack's thermal performance under various discharge currents and heating rates associated with those currents. Verbrugge ${ }^{7}$ examined the effect of a variety of parameters (i.e., convective heat-transfer coefficient, exchange current density, tortuosity, etc.) on the center temperature of a cell stack of a lithium-ion cell and how thermal runaway in a single cell can affect the remaining cells in the stack. Both Chen and Evans $^{6}$ and Verbrugge ${ }^{7}$ based their models on idealized versions of the system. Pals and Newman ${ }^{8}$ developed a mathematical model to predict thermal behavior of a lithium/polymer battery, based on the one-dimensional model by Doyle et al. ${ }^{9}$ In their paper, Pals and Newman ${ }^{8}$ present simulation results for the $\mathrm{Li} / \mathrm{PEO}_{15}-\mathrm{LiCF}_{3} \mathrm{SO}_{3} /$ $\mathrm{TiS}_{2}$ system operating isothermally, adiabatically, and with transfer of heat to the surroundings. We have taken a similar approach, also based on the one-dimensional model by Doyle et al. ${ }^{9}$ In our case, we have included a decomposition reaction for the carbon anode in the energy balance.

\section{Model Development}

We have modeled the galvanostatic charge/discharge behavior of the $\mathrm{Li}_{x} \mathrm{C}_{6} / \mathrm{Li}_{y} \mathrm{NiO}_{2}$ cell sandwich, as shown in Fig. 1, based on the model developed by Doyle et al. ${ }^{9}$ This is a pseudo two-dimensional problem with transport of lithium ions across the cell and within the solid-phase particles, which are assumed to be spherical. Further-

\footnotetext{
* Electrochemical Society Student Member.

** Electrochemical Society Active Member.

z E-mail: rew@sc.edu
}

more, in order to avoid unnecessary complexity, volume changes associated with electrode expansion and contraction during cycling have been ignored.

A variety of side reactions may take place in a lithium-ion battery at elevated temperatures. For example, the electrolyte may decompose,${ }^{10}$ the positive electrode may decompose, ${ }^{11}$ and the negative electrode may decompose. ${ }^{12}$ Of these, we have included a decomposition reaction of the negative electrode in our energy balance ${ }^{12}$

$$
2 \mathrm{Li}_{x} \mathrm{C}_{6}+\delta \mathrm{C}_{3} \mathrm{H}_{4} \mathrm{O}_{3} \rightarrow \delta \mathrm{Li}_{2} \mathrm{CO}_{3}+\delta \mathrm{C}_{2} \mathrm{H}_{4}+2 \mathrm{Li}_{x-\delta} \mathrm{C}_{6}
$$

where $\delta$ represents the extent-of-reaction. This reaction is the same reaction that has been proposed to take place during the first charge cycle of a lithium-ion battery when the solid-electrolyte interface is formed. ${ }^{12}$ This is an exothermic reaction with a heat of reaction of $-289 \mathrm{~kJ} / \mathrm{mol}$ of lithium reacted. ${ }^{13}$ We have chosen this mechanism to include in an energy balance because it occurs at a relatively low temperature in comparison to the positive electrode and electrolyte decomposition reactions. Von Sacken et al. ${ }^{12}$ described a first-order reaction rate for the reaction described in Eq.1

$$
\mathfrak{R}=k_{1} a_{4} \bar{c}_{\mathrm{s}, 1}^{*} \exp \left(-E_{\mathrm{A}} / R T\right)
$$

where $\Re$ is the rate of reaction, $k_{1}$ is the reaction rate constant, $\bar{c}_{\mathrm{s}, 1}^{*}$ is the local surface average concentration of lithium at the surface of

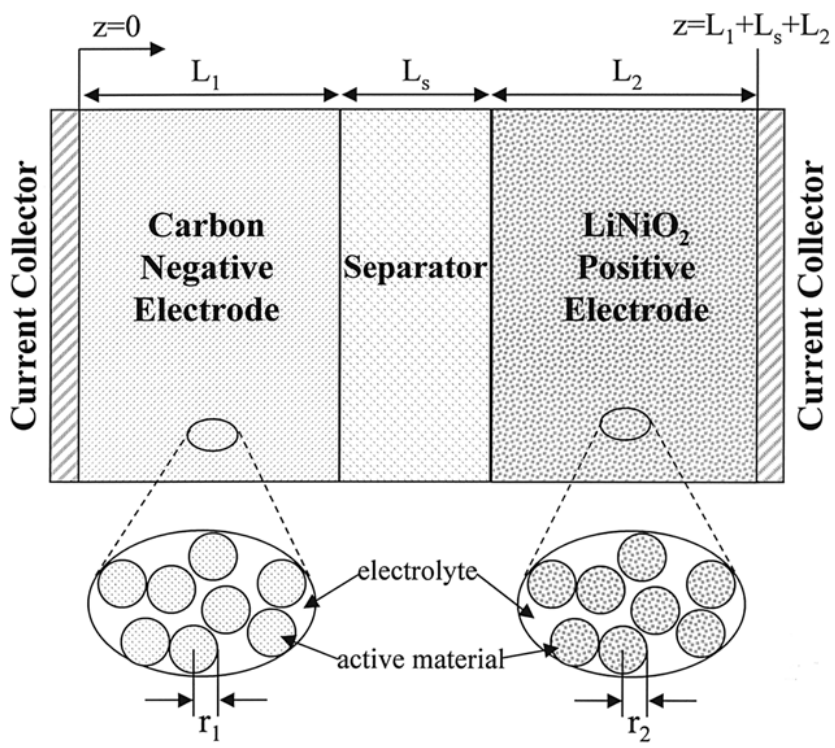

Figure 1. Idealized schematic diagram of cell sandwich consisting of negative electrode, separator, and positive electrode. The active material is depicted and modeled as spherical particles. 
each of the particles in the negative electrode (calculated from an overall mass balance in the particles of the electrode according to the equations shown in Appendix A), $E_{\mathrm{A}}$ is the activation energy for Eq. $1, R$ is the universal gas constant, and $T$ is the cell temperature. The values for $k_{1}$ and $E_{\mathrm{A}}$ were estimated in order to fit the experimental data given by Von Sacken et al. ${ }^{12}$

We have added a term that accounts for energy liberated from the reaction in Eq. 1 (i.e., $-\Delta H_{\mathrm{rxn}} \Re$ ) to a general energy balance of an insertion battery system described by Rao and Newman. ${ }^{14}$ The assumptions used by Rao and Newman ${ }^{14}$ still apply: (i) the temperature is uniform throughout the cell at a given instant in time; (ii) the heat capacity of the cell $\left(C_{\mathrm{p}}\right)$ is calculated as an average of all the components of the cell and is assumed to be a constant evaluated at $T=25^{\circ} \mathrm{C}$; and (iii) enthalpy of mixing and phase-change terms were neglected; further discussion about the effects of these terms can be found in Ref. 15.

Therefore, the energy balance in the system can be expressed as

$$
\begin{aligned}
\rho C_{\mathrm{p}} \frac{\partial T}{\partial t}-\dot{Q}=-\frac{1}{v_{\mathrm{c}}}\left[\int_{v_{1}} a_{3,1} i_{\mathrm{n}, 1} U_{\mathrm{H}, 1} d v_{1}\right. & \left.+\int_{v_{2}} a_{3,2} i_{\mathrm{n}, 2} U_{\mathrm{H}, 2} d v_{2}\right] \\
& -a_{1} i_{\mathrm{app}} V-\Delta H_{\mathrm{rxn}} \Re
\end{aligned}
$$

where $\rho$ is the cell density, $C_{\mathrm{p}}$ is the constant-pressure cell heat capacity, $t$ is time, $\dot{Q}$ is the heat transfer rate from the cell to the environment, $a_{3,1}$ and $a_{3,2}$ are the interfacial areas of solid-phase particles per unit volume of porous electrodes for the anode and cathode, respectively (see Appendix B), $i_{\mathrm{n}, 1}$ and $i_{\mathrm{n}, 2}$ are the local interfacial current densities in the anode and cathode, respectively, $U_{\mathrm{H}, 1}$ and $U_{\mathrm{H}, 2}$ are the local enthalpy potentials, ${ }^{14} v_{1}$ and $v_{2}$ are the volumes of the anode and

\section{Table I. Initial conditions of the cell.}

Variable

Initial value

\begin{tabular}{lc}
$c_{0}$ & \multicolumn{2}{c}{$1000 \mathrm{~mol} / \mathrm{m}^{3}$} \\
$\phi_{2}$ & $0.0 \mathrm{~V}$ \\
$T_{0}$ & $298 \mathrm{~K}$ \\
$i_{2}$ & \multicolumn{2}{c}{$0 \mathrm{~A} / \mathrm{m}^{2}$} \\
& \multicolumn{2}{c}{$\mathrm{Li}_{x} \mathrm{C}_{6}$} & $\mathrm{Li}_{y} \mathrm{NiO}_{2}$ \\
\cline { 2 - 3 }$c_{\mathrm{s}, \mathrm{k} 0}\left(\mathrm{~mol} / \mathrm{m}^{3}\right)$ & $1.2 \times 10^{4}\left(x_{0}=0.5\right) \quad 1.0 \times 10^{4}\left(y_{0}=0.45\right)$
\end{tabular}

cathode, respectively, $v_{\mathrm{c}}$ is the volume of the cell, $a_{1}$ is the geometric electrode surface area per unit volume of the cell, $i_{\text {app }}$ is the applied cell current density, and $V$ is the cell potential. The first two terms on the right side of Eq. 3 describe the electrochemical heat generation rate, as described by Rao and Newman. ${ }^{14}$ The heat-transfer rate from the cell to the environment, $\dot{Q}$, is represented by

$$
\dot{Q}=a_{1} a_{2} h_{\mathrm{c}}\left(T_{\mathrm{amb}}-T\right)
$$

where $a_{2}$ is the ratio of cell surface area to geometric electrode surface area, $h_{\mathrm{c}}$ is the heat-transfer coefficient for the cell, and $T_{\mathrm{amb}}$ is the ambient temperature outside the cell. Note that by multiplying by $a_{1}$ and $a_{2}$, the heat-transfer from the cell is per unit volume of the cell.

The enthalpy potential is given by ${ }^{14}$

$$
U_{\mathrm{H}, \mathrm{k}}=-T^{2}\left[\frac{1}{T} \frac{d U_{\mathrm{k}}}{d T}-\frac{U_{\mathrm{k}}}{T^{2}}\right] \quad k=1,2
$$

\section{Table II. Model parameters.}

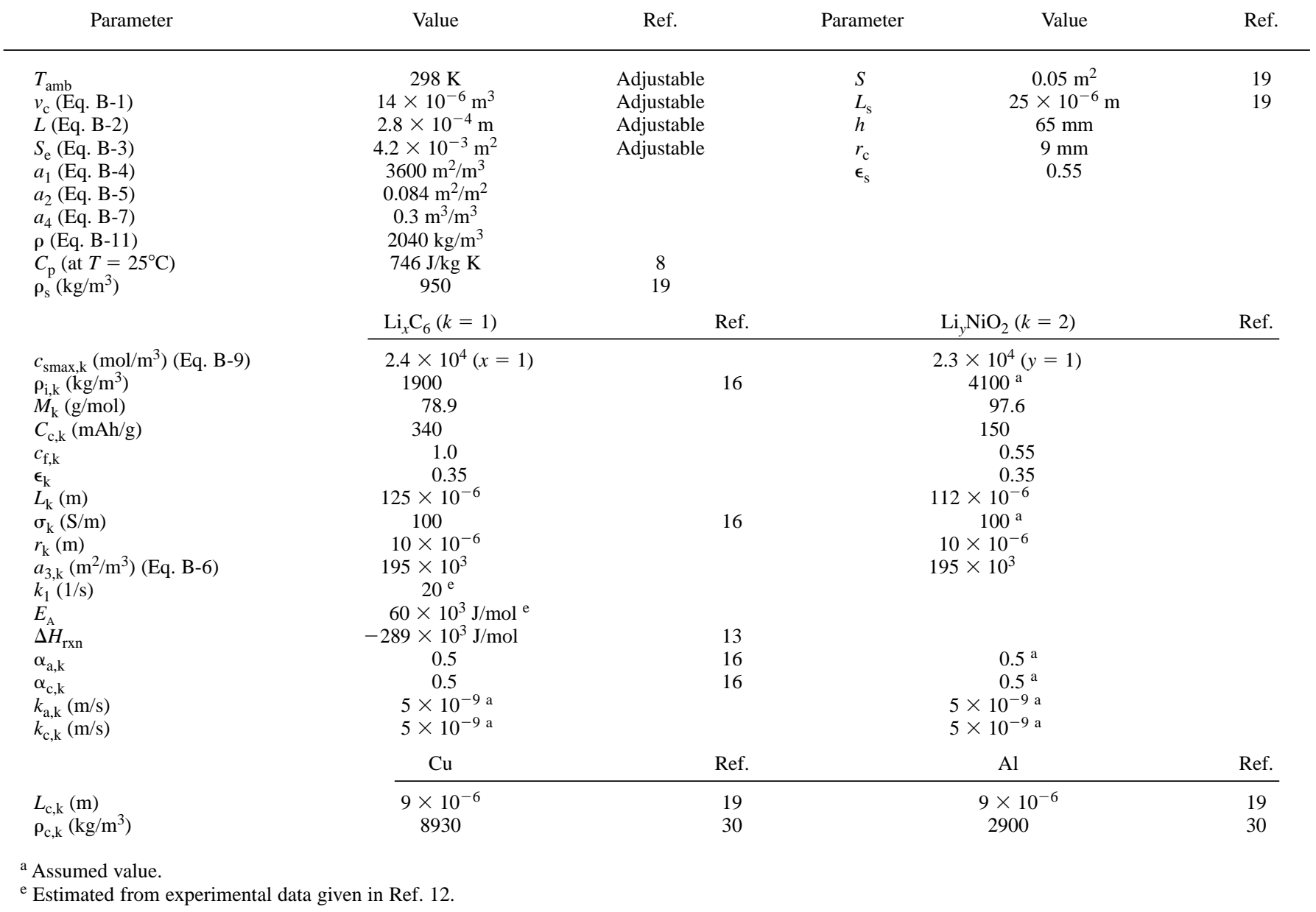




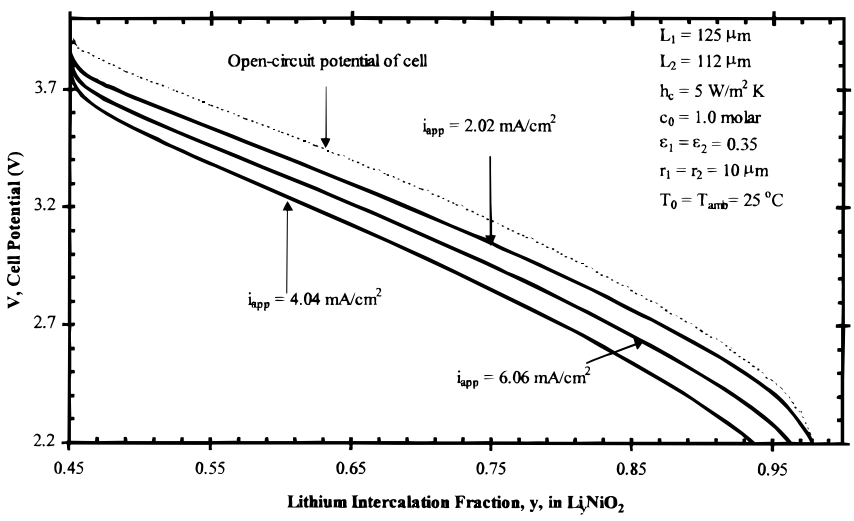

Figure 2. Cell potential vs. state-of-discharge at three different galvanostatic discharge rates. The dashed line represents the open-circuit potential of the cell.

where $U_{\mathrm{k}}$ is the open-circuit potential of electrode $\mathrm{k}$ with respect to a lithium reference electrode. Since $d U_{\mathrm{k}} / d T$ is not known and expected to be small, Eq. 5 can be approximated as ${ }^{14}$

$$
U_{\mathrm{H}, \mathrm{k}}=U_{\mathrm{k}}
$$

Substituting Eq. 6 into Eq. 3, followed by integrating the appropiate terms over the electrode volumes $\left(v_{1}\right.$ and $\left.v_{2}\right)$, and considering that the local interfacial current densities are defined negative and positive for the cathodic and anodic reactions, respectively, yields

$$
\rho C_{\mathrm{p}} \frac{\partial T}{\partial t}-\dot{Q}=\frac{I}{v_{\mathrm{c}}}\left(U_{2}-U_{1}\right)-a_{1} i_{\mathrm{app}} V-\Delta H_{\mathrm{rxn}} \Re
$$

where $I$ is the total applied current for the cell. Knowing that the difference between $U_{2}$ and $U_{1}$ is the open-circuit potential of the cell $\left(U_{\text {ocp }}\right)$ and that the ratio of $I / v_{\mathrm{c}}$ is equal to $a_{1}$ multiplied by $i_{\text {app }}$, Eq. 7 becomes

$$
\rho C_{\mathrm{p}} \frac{\partial T}{\partial t}=\dot{Q}+a_{1} i_{\mathrm{app}}\left(U_{\text {ocp }}-V\right)-\Delta H_{\mathrm{rxn}} \Re
$$

The term on the left of Eq. 8 accounts for the sensible heat, the first term on the right accounts for the heat transfer to the ambient, the second term accounts for ohmic heating of the cell, and the last term accounts for the heat generated during the decomposition reaction of the anode.

The remaining equations governing the performance of the lithium-ion cell system have been described by others ${ }^{9,16}$ and are summarized in Appendix A. The initial conditions for the simulations are shown in Table I.

Equation 8 was used for the energy balance in the lithium-ion cell under normal operation of the cell before the separator melts (i.e., below $135^{\circ} \mathrm{C}$ ). If the temperature of the cell rises above $135^{\circ} \mathrm{C}$, we assume that the separator melts, and the model with the equations described above no longer applies. Consequently, when the cell is above $135^{\circ} \mathrm{C}$, the model of the cell is changed to that for a batch reactor (see Eq. A-29) with an energy balance given by Eq. 8 with no ohmic heating (i.e., the second term on the right of Eq. 8 is dropped).

\section{Results and Discussion}

We modeled a cell sandwich (see Fig. 1) consisting of a petroleum coke carbon negative electrode, a microporous polyethylene separator, and a nickel dioxide positive electrode. The electrolyte used was lithium perchlorate with propylene carbonate (PC) as the solvent. The polyethylene separator was assumed to be inert with a void fraction of $\epsilon_{\mathrm{s}}=0.55$. A nickel dioxide positive electrode was chosen because the open-circuit potential function available for nickel dioxide describes the entire range of intercalated lithium $(0.45<y<$ $1.0)^{17}$; in addition, nickel dioxide electrodes have a higher capacity than cobalt dioxide electrodes. However, nickel dioxide electrodes have been found to be less safe than cobalt dioxide electrodes. ${ }^{18}$ Lithium perchlorate was chosen as the electrolyte because transport data are available for this electrolyte. Important model parameters for this system are listed in Table II. The cell density was calculated based on the density of the individual components of a lithium-ion battery, as shown in Appendix B. The maximum solid-phase concentrations were calculated based on the theoretical density of the solid-phase active materials when $x=1$ and $y=1$, for the negative and positive electrode, respectively.

Figure 2 presents the cell potential as a function of the lithium fraction, $y$, in $\mathrm{Li}_{y} \mathrm{NiO}_{2}$, where the cell potential, $V$, is calculated from the differences in the solid-phase potential at the two current collectors

$$
V=\left.\phi_{1}\right|_{z=\mathrm{L}_{1}+\mathrm{L}_{\mathrm{s}}+\mathrm{L}_{2}}-\left.\phi_{1}\right|_{z=0}
$$

Intercalation fractions for the cathode material range from a fraction of $y=0.45$ in the fully charged state to $y \approx 1.0$ in the fully dis-

Table III. Approximate expressions for the diffusion coefficients and ionic conductivities as a function of temperature.

\begin{tabular}{|c|c|c|c|}
\hline$D_{0+}\left(\mathrm{m}^{2} / \mathrm{s}\right)$ & $1 \times 10^{-8} \mathrm{e}^{\left(-\frac{1200}{T}\right)}$ & $1.6 \times 10^{-10}$ & 20,21 \\
\hline$D_{0-}\left(\mathrm{m}^{2} / \mathrm{s}\right)$ & $26 \times 10^{-4} \mathrm{e}^{\left(-\frac{4500}{T}\right)}$ & $6.5 \times 10^{-10}$ & 20,21 \\
\hline$D\left(\mathrm{~m}^{2} / \mathrm{s}\right)$ & Eq. 10 & $2.6 \times 10^{-10}$ & 20,21 \\
\hline$t_{+}^{0}$ & Eq. 11 & 0.20 & 20,21 \\
\hline$D_{\mathrm{s} 1}\left(\mathrm{~m}^{2} / \mathrm{s}\right)$ & $2 \times 10^{-13} \mathrm{e}^{\left(-\frac{500}{T}\right)}$ & $3.9 \times 10^{-14}$ & 23,24 \\
\hline$D_{\mathrm{s} 2}\left(\mathrm{~m}^{2} / \mathrm{s}\right)$ & $7 \times 10^{-7} \mathrm{e}^{\left(-\frac{3100}{T}\right)}$ & $2.0 \times 10^{-11}$ & 25,26 \\
\hline$\kappa_{\mathrm{K}}(\mathrm{S} / \mathrm{m})$ & $\left.1500^{*} \kappa_{\mathrm{k}}\right|_{25^{\circ} \mathrm{C}} \mathrm{e}^{\left(\frac{-2200}{T}\right.}$ & $\left.\mathrm{K}_{\mathrm{k}}\right|_{25^{\circ} \mathrm{C}} \mathrm{b}$ & 7,27 \\
\hline
\end{tabular}


charged state. In actual cells, the $y$ fraction in fully discharged cells only approaches values close to 1.0 due to the small amount of lithium lost during the first cycle. The negative electrode fraction, $x$, in $\mathrm{Li}_{x} \mathrm{C}_{6}$, cycles between a fully charged fraction of 0.5 and a fully discharged fraction approaching 0.0. The dotted line in Fig. 2 represents the open-circuit potential of the cell and was calculated from Eq. A-15 and A-16, which describe the open-circuit potential for both electrodes as a function of solid-phase lithium concentration at $T_{\mathrm{amb}}=25^{\circ} \mathrm{C}$. The applied current densities of 2.02, 4.04, and $6.06 \mathrm{~mA} / \mathrm{cm}^{2}$, represent $\mathrm{C} / 2,1 \mathrm{C}$, and $3 \mathrm{C} / 2$ theoretical discharge rates (see Appendix B), respectively. A heat-transfer coefficient of $5 \mathrm{~W}$ per square meter of cell surface area per kelvin was used for most results shown in this paper. This value was used to represent a cell in a battery pack. The cell was assumed to be an 18650 sized cell (i.e., a cell with an $18 \mathrm{~mm}$ diam and $65.0 \mathrm{~mm}$ height) which has approximately $500 \mathrm{~cm}^{2}$ of geometric electrode surface area for each electrode in the jelly roll per $42 \mathrm{~cm}^{2}$ of external cell surface area. ${ }^{19}$ These values are used to calculate the parameter $a_{2}$ (see Appendix B).

Before going into the analysis of the influence of some design parameters on the thermal behavior of lithium-ion batteries, it is useful to predict approximately the influence of the temperature dependence of some of the transport properties (solid diffusion coefficients, electrolyte diffusion coefficient, electrolyte transference number, solid-phase or electronic conductivity, and solution-phase or ionic conductivity) on the behavior of the cell. Unfortunately, transport properties for lithium-ion cells are not available for a wide range of temperatures. Consequently, we made estimates of these based on the following approximations

1. The temperature dependence of the diffusion coefficients of $\mathrm{Li}^{+}$in the solid and solution phases, the ionic conductivity, and the electronic conductivity follow an Arrhenius expression.

2 . The diffusion coefficient of the electrolyte $(D)$ was estimated from the data given by Soetens et al. ${ }^{20}$; in their work, the diffusion coefficients for $\mathrm{LiBF}_{4}$ in $\mathrm{PC}$ were calculated using molecular dynamic simulations at two different temperatures: 25 and $50^{\circ} \mathrm{C}$. A ratio between the diffusion coefficient of $\mathrm{LiClO}_{4} / \mathrm{PC}$ at $25^{\circ} \mathrm{C}$ given by Sullivan et al. ${ }^{21}$ and the one for $\mathrm{LiBF}_{4} / \mathrm{PC}$ given by Soetens et al. ${ }^{20}$ was calculated and used to determine $D_{0+}$ and $D_{0-}$ of $\mathrm{LiClO}_{4} / \mathrm{PC}$ at $50^{\circ} \mathrm{C}$; with these two values Arrhenius expressions for $D_{0+}$ and $\mathrm{D}_{0-}$ of $\mathrm{LiClO}_{4} / \mathrm{PC}$ were calculated; these expressions are presented in Table III. The diffusion coefficient of the electrolyte $(D)$ was calculated from the diffusion coefficient of the different species in the solvent $\left(D_{0+}\right.$ and $\left.D_{0-}\right)$ by using the following expression ${ }^{22}$

$$
D=\frac{D_{0+} D_{0-}\left(z_{+}-z_{-}\right)}{z_{+} D_{0+}-z_{-} D_{0-}}
$$

where $z_{+}$and $z_{-}$are 1 and -1 , respectively. The transference number of the lithium ions in the solvent $\left(t_{+}^{0}\right)$ was calculated from the diffusion coefficient of the different species in the solvent ${ }^{22}$

$$
t_{+}^{0}=\frac{z_{+} D_{0+}}{z_{+} D_{0+}-z_{-} D_{0-}}
$$

3. The diffusion coefficient of the lithium ion in the petroleum coke anode $\left(D_{\mathrm{s} 1}\right)$ was estimated from the data given by Yu et al. ${ }^{23}$; in their work, diffusion coefficients for an Aldrich artificial graphite at two different temperatures $\left(25\right.$ and $\left.55^{\circ} \mathrm{C}\right)$ were measured experimentally using impedance techniques. The same procedure used to estimate the diffusion coefficient of the electrolyte was used to estimate the expression for $D_{\mathrm{s} 1}$ in petroleum coke based on the value given by Doyle et al. ${ }^{24}$ The Arrhenius expression for $D_{\mathrm{s} 1}$ is given in Table III.

4. The solid diffusion coefficient of lithium ions in the $\mathrm{Li}_{y} \mathrm{NiO}_{2}$ cathode $\left(D_{\mathrm{s} 2}\right)$ was estimated from the data given by Basu and Worrell ${ }^{25}$; in their work, diffusion coefficients for $\mathrm{Li}_{x} \mathrm{TaS}_{2}$ at two different temperatures $\left(30\right.$ and $70^{\circ} \mathrm{C}$ ) were measured experimentally. The procedure explained before was used to estimate the expression for $D_{\mathrm{s} 2}$ in $\mathrm{Li}_{y} \mathrm{NiO}_{2}$ based on the value given by Bruce et al. ${ }^{26}$ The Arrhenius expression for $D_{\mathrm{s} 2}$ is presented in Table III.
5. The ionic conductivity of the electrolyte $\left(\kappa_{\mathrm{K}}\right)$ was estimated from the expression given by Verbrugge ${ }^{7}$ for the temperature dependence of the ionic conductivity of $\mathrm{LiAsF}_{6}$ in PC (1 M). The same procedure used to estimate the diffusion coefficients was used to estimate the ionic conductivity of $\mathrm{LiClO}_{4}$ in $\mathrm{PC}$, based on the expression given by Doyle. ${ }^{27}$ The expression for the ionic conductivity is given in Table III.

6 . The influence of the electronic conductivity of the solid phases $\left(\sigma_{\mathrm{k}}\right)$ on the predicted temperature profiles was checked by changing the values of $\sigma_{k}$ by one order of magnitude. No changes were observed in the results based on these changes in $\sigma_{k}$.

Figure 3 presents the predicted temperature of the cell as a function of time when the transport properties were evaluated at different temperatures: 25,75 , and $125^{\circ} \mathrm{C}$. This figure shows the results for a galvanostatic discharge (at $12.12 \mathrm{~mA} / \mathrm{cm}^{2}$ ) to $2.2 \mathrm{~V}$ cutoff voltage, followed by the relaxation of the cell (no current applied) for an additional $20 \mathrm{~min}$. The simulation started with an initial temperature of $75^{\circ} \mathrm{C}$. It was predicted to take about $4.00,5.20$ and $6.00 \mathrm{~min}$ to reach the cutoff voltage at this discharge rate for the transport properties evaluated at 25,75 , and $125^{\circ} \mathrm{C}$, respectively. The additional conditions of this simulation are given on the figure. The purpose of this figure is to demonstrate the effect of using the transport properties at $25^{\circ} \mathrm{C}$ vs using them at a temperature of $125^{\circ} \mathrm{C}$ (maximum temperature reached) or at the initial temperature $T_{0}=75^{\circ} \mathrm{C}$. Curve 1 presents the results with all the transport properties $\left(D, t_{+}^{0}, \kappa_{\mathrm{\kappa}}, D_{\mathrm{s} 1}\right.$, and $D_{\mathrm{s} 2}$ ) evaluated at $25^{\circ} \mathrm{C}$, curve 2 shows the results with all the properties evaluated at $75^{\circ} \mathrm{C}$, while curve 3 gives the results when all the properties are evaluated at $125^{\circ} \mathrm{C}$. As shown in Fig. 3, the qualitative behavior of the three curves is the same, and the temperatures predicted are close to one another. Since the three curves in Fig. 3 are similar and close to one another, and experimental data are not available for the transport properties of this system at different temperatures, all the transport properties used here were evaluated at $25^{\circ} \mathrm{C}$.

Figure 4 presents the predicted temperature of the cell vs. stateof-discharge when the cell was discharged galvanostaticaly at different current densities to a $2.2 \mathrm{~V}$ cutoff voltage. The $15^{\circ} \mathrm{C}$ temperature rise at the $4.04 \mathrm{~mA} / \mathrm{cm}^{2}$ discharge rate, as shown in Fig. 4, is approximately in agreement with the measured temperature rise observed in our laboratory for an $18650 \mathrm{Li}_{x} \mathrm{C}_{6} / \mathrm{Li}_{y} \mathrm{CoO}_{2}$ cell at the same discharge rate. As expected, because of ohmic heating, a higher discharge rate heats the cell faster, as shown in Fig. 4.

Figure 5 shows how the predicted cell temperature depends on the heat-transfer coefficient at the surface of the cell, for a discharge current density of $12.12 \mathrm{~mA} / \mathrm{cm}^{2}$. The values for the heat-transfer coefficient represented in this figure range from 0 to $25 \mathrm{~W} /\left(\mathrm{m}^{2} \mathrm{~K}\right)$. This range represents various degrees of insulation observed from placing cells in battery packs where $h_{\mathrm{c}}$ would be expected to vary between about 0 to $25 \mathrm{~W} /\left(\mathrm{m}^{2} \mathrm{~K}\right){ }^{6}$

Figure 6 presents the predicted temperature of the cell for different positive and negative electrode porosities. The cell was dis-

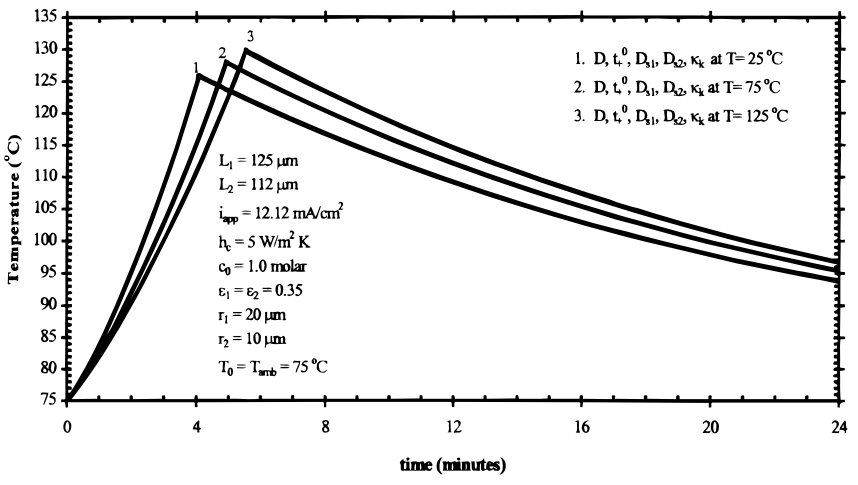

Figure 3. Effect of the transport properties in the temperature of the cell with galvanostatic discharge to $2.2 \mathrm{~V}$ and relaxation (no current applied) for 20 additional min. Initial and ambient temperatures of $75^{\circ} \mathrm{C}$ were used. 


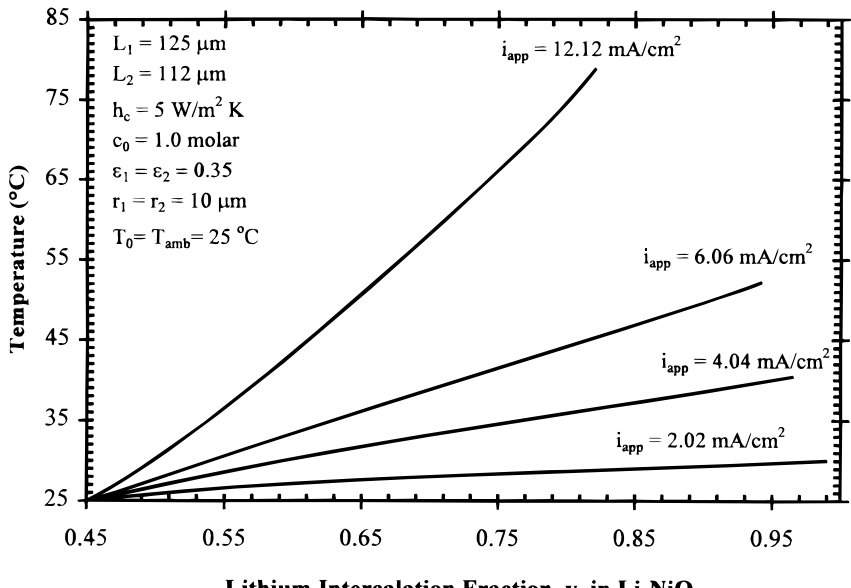

Lithium Intercalation Fraction, $y$, in $\mathrm{Li}_{y} \mathrm{NiO}_{2}$

Figure 4. Cell temperature vs. state-of-discharge for different applied cell current densities at an initial and ambient temperature of $25^{\circ} \mathrm{C}$ with galvanostatic discharge to a $2.2 \mathrm{~V}$ cutoff potential. The current densities $12.12,6.06$, 4.04 , and $2.02 \mathrm{~mA} / \mathrm{cm}^{2}$ represent approximately $3 \mathrm{C}, 3 / 2 \mathrm{C}, 1 \mathrm{C}$, and $\mathrm{C} / 2$ theoretical discharge rates, respectively.

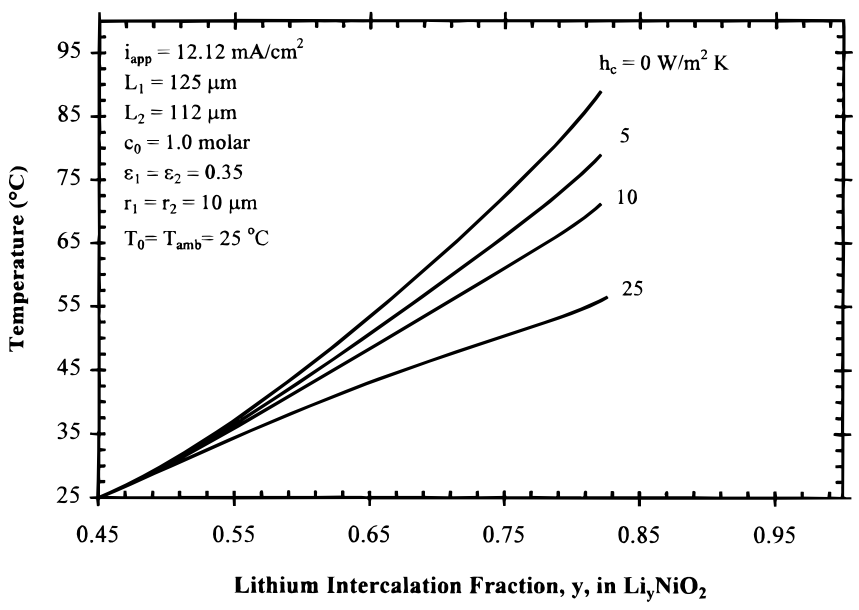

Figure 5. Cell temperature vs. state-of-discharge for different heat-transfer coefficients at an initial and ambient temperature of $25^{\circ} \mathrm{C}$ with galvanostatic discharge to a $2.2 \mathrm{~V}$ cutoff potential.

charged galvanostaticaly, $4.04 \mathrm{~mA} / \mathrm{cm}^{2}$, to a $2.2 \mathrm{~V}$ cutoff voltage. Nagarajan et al. ${ }^{28}$ showed that the porosity of a porous electrode can vary between 0.17 and 0.375 with different combinations of particle sizes. Since Nagarajan et al. ${ }^{28}$ showed that the various porosities can be achieved only with different particle size distributions, the $10 \mu \mathrm{m}$ particle size used to prepare Fig. 6 represents an average value. As shown in Fig. 6, when the porosity of the electrodes is reduced, the temperature in the cell rises, as expected since more active material is in the cell.

Figure 7 presents predicted cell temperatures vs. state-of-discharge for different positive and negative electrode thicknesses. The applied current density was varied in order to keep constant the theoretical discharge rate $(1 \mathrm{C})$, while an initial and ambient temperature of $25^{\circ} \mathrm{C}$ and a galvanostatic discharge to a $2.2 \mathrm{~V}$ cutoff potential was used. This figure shows that thinner electrodes heat up less during this theoretical discharge rate of $1 \mathrm{C}$. Cells constructed of thinner electrodes operate at a relatively lower concentration overpotential and thus have a lower heating rate.

Figure 8 presents the predicted temperatures and cell voltages for different negative electrode particle sizes. The cell was discharged galvanostaticaly to a $2.2 \mathrm{~V}$ cutoff voltage. Figure $8 \mathrm{a}$ shows that the

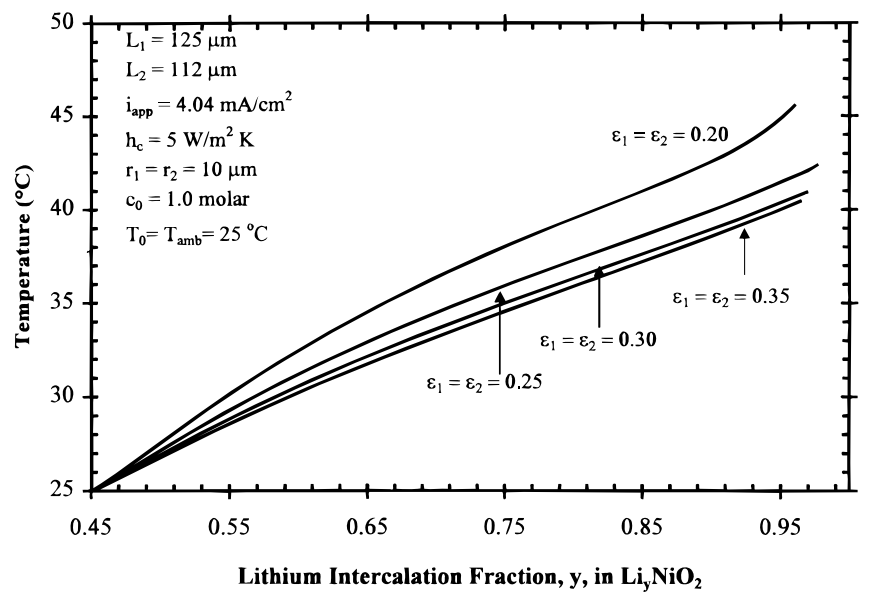

Figure 6. Cell temperature vs. state-of-discharge for different positive and negative electrode porosities at an initial and ambient temperature of $25^{\circ} \mathrm{C}$ with galvanostatic discharge to a $2.2 \mathrm{~V}$ cutoff potential.

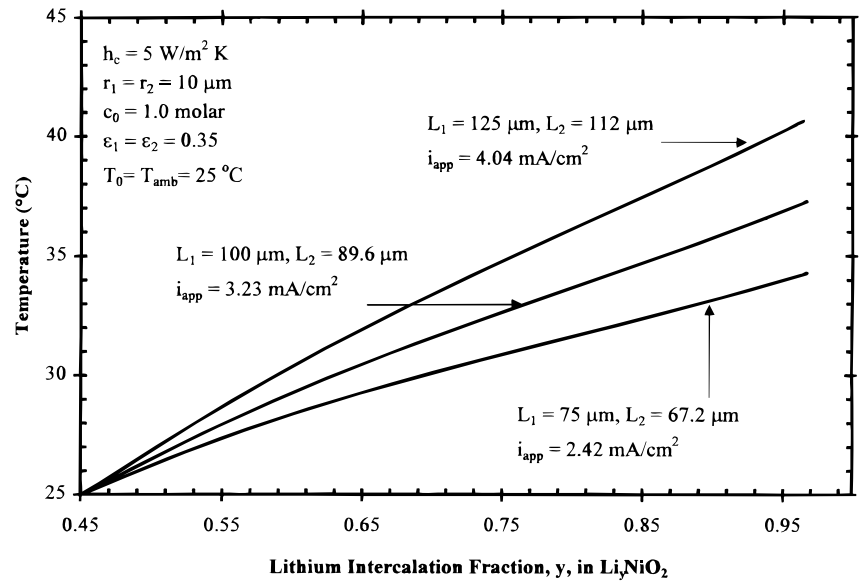

Figure 7. Cell temperature vs. state-of-discharge for different positive and negative electrode thicknesses at an initial and ambient temperature of $25^{\circ} \mathrm{C}$ with galvanostatic discharge to a $2.2 \mathrm{~V}$ cutoff potential. The ratio between positive electrode thickness and negative electrode thickness held constant. The current density was changed in order to maintain the theoretical discharge rate constant in $1 \mathrm{C}$.

heating rate of the cell depends strongly on the active material particle size in the negative electrode at moderate theoretical discharge rates $\left(6.06 \mathrm{~mA} / \mathrm{cm}^{2}, 3 \mathrm{C} / 2\right)$. Note that the particle size in the positive electrode is relatively unimportant because of the high lithium diffusion coefficient in nickel dioxide. Figure $8 \mathrm{~b}$ shows that the bigger the particle size in the negative electrode the faster the cell reaches the cutoff potential due to polarization. This effect is due to an increase in the solid-state diffusional limitations and an increase in the surface overpotential (due to smaller surface area for the electrochemical reaction), because of the large particle size. Since cells with larger particles reach the cutoff voltage during discharge in less time, the ohmic heat generated is larger (according to the second term on the right of Eq. 8) causing a higher temperature (see Fig. 8a). At discharge rates below $\mathrm{C} / 2$, the effect of the particles size in the negative electrode on the temperature of the cell was found to be insignificant.

Figure 9 presents the predicted temperatures and the cell potentials at high discharge rates. The cell was discharged galvanostaticaly at different current densities to $2.2 \mathrm{~V}$ cutoff. Figure 9a shows that the temperature increases with larger discharge rates, due to ohmic heating. However, it is important to point out that the temperatures shown in Fig. 9a are the maximum that can be reached in the 

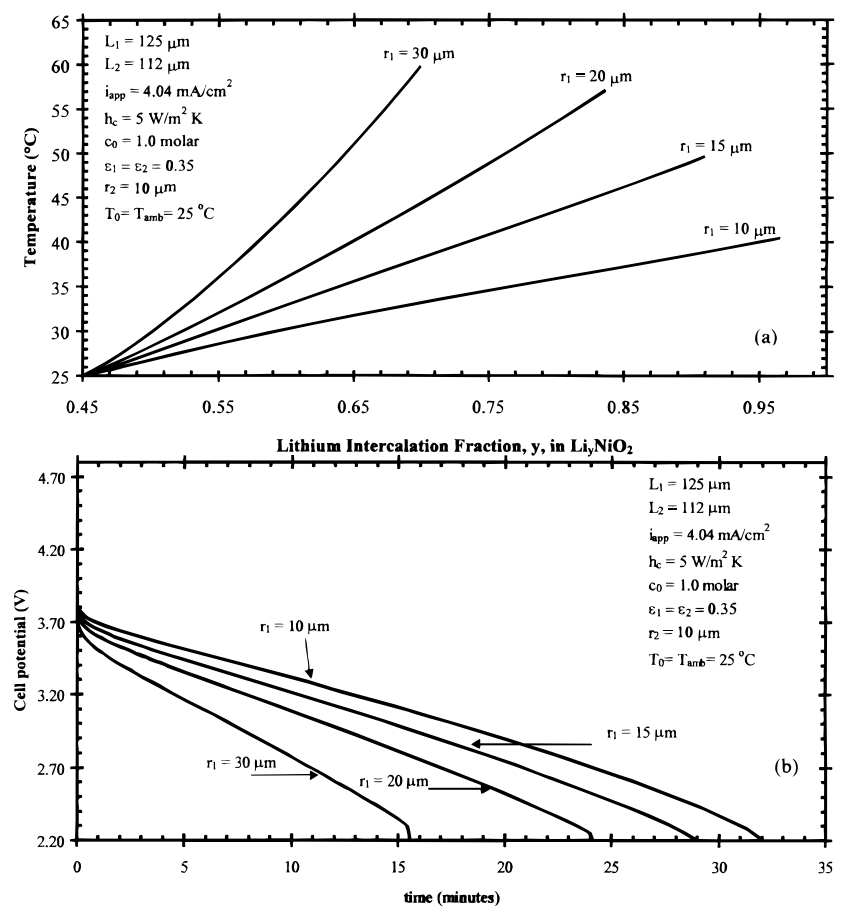

Figure 8. Results of the simulation for different negative electrode particle sizes at an initial and ambient temperature of $25^{\circ} \mathrm{C}$ with galvanostatic discharge to a $2.2 \mathrm{~V}$ cutoff potential: (a) temperature vs. state of discharge, and (b) cell potential vs. time.
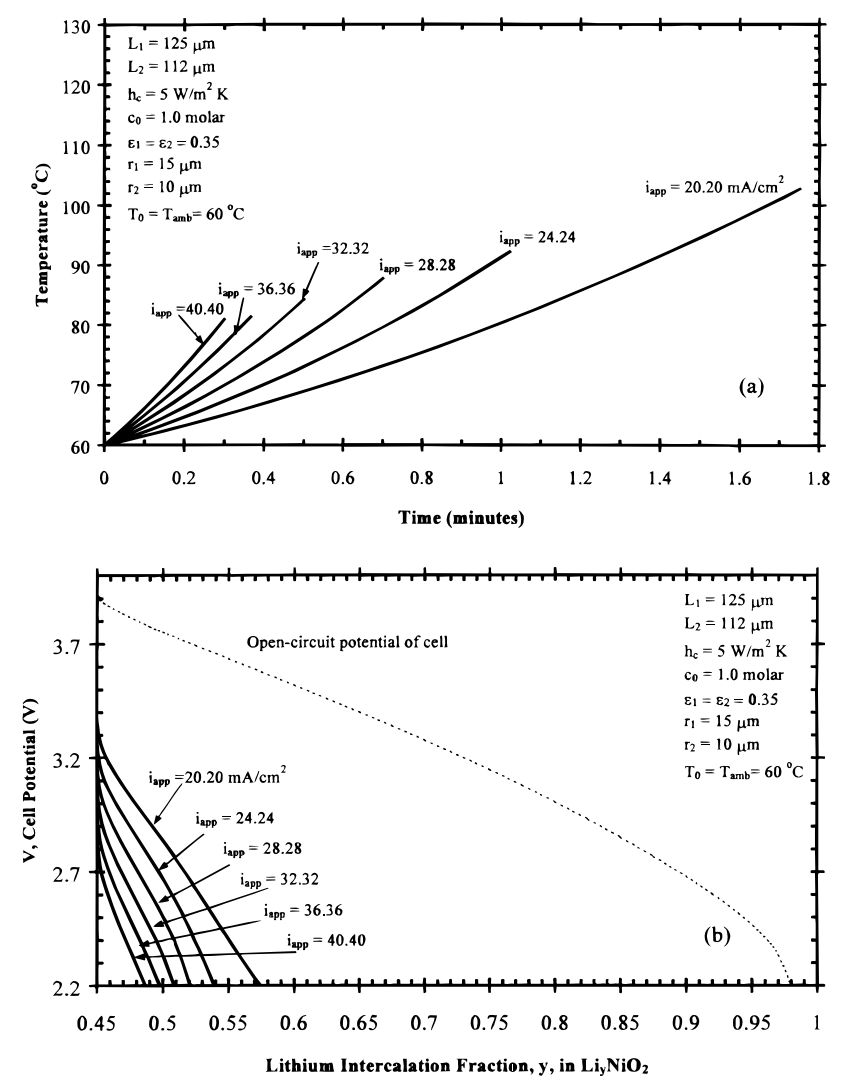

Figure 9. Results of the simulation at high discharge rates at an initial and ambient temperature of $60^{\circ} \mathrm{C}$ with galvanostatic discharge to $2.2 \mathrm{~V}$ cutoff potential, (a) temperature vs. time, and (b) cell potential vs. state of discharge. The current densities 20.20, 24.24, 28.28, 32.32, 36.26, and $40.04 \mathrm{~mA} / \mathrm{cm}^{2}$ represent approximately $5 \mathrm{C}, 6 \mathrm{C}, 7 \mathrm{C}, 8 \mathrm{C}, 9 \mathrm{C}$, and $10 \mathrm{C}$ theoretical discharge rates, respectively.
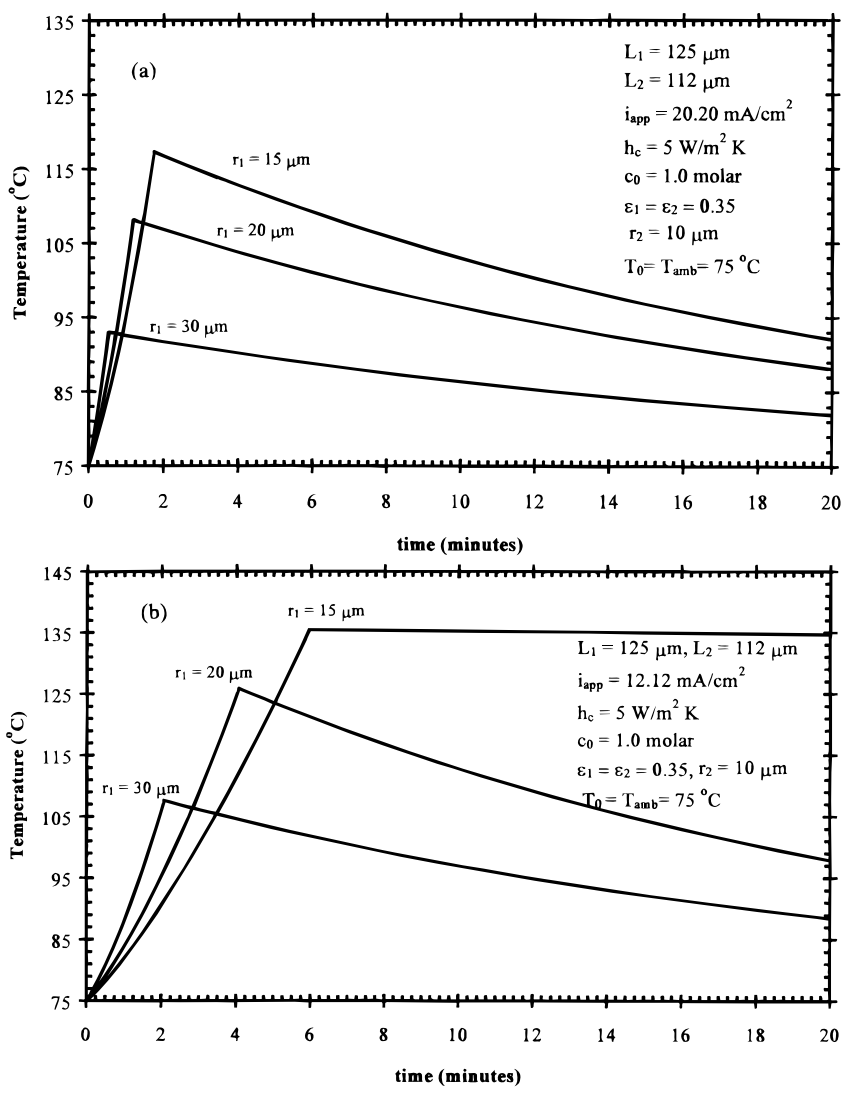

Figure 10. Results of the simulation for different negative electrode particle sizes at an initial and ambient temperature of $75^{\circ} \mathrm{C}$ with galvanostatic discharge to a $2.2 \mathrm{~V}$ cutoff potential and relaxation for 20 additional min: (a) temperature vs. time at $i_{\text {app }}=20.20 \mathrm{~mA} / \mathrm{cm}^{2}$ and (b) temperature vs. time at $i_{\text {app }}=12.12 \mathrm{~mA} / \mathrm{cm}^{2}$.

system because the cells have already reached the $2.2 \mathrm{~V}$ cutoff potential, according to the results presented in Fig. $9 \mathrm{~b}$.

Figure 10 presents the predicted cell temperature vs. time for different negative electrode material particle sizes at an initial temperature of $75^{\circ} \mathrm{C}$ for a galvanostatic discharge to $2.2 \mathrm{~V}$ and a resting period (no current) for 20 additional min. Two different current densities were used: 20.20 in Fig. 10a and $12.12 \mathrm{~mA} / \mathrm{cm}^{2}$ in Fig. 10b. As expected, the behavior shown in the figures indicates a heating process during the discharge (ohmic heating) and a cooling process after the cutoff potential has been reached. Figures 10a and $\mathrm{b}$ show that electrodes with larger particle sizes heat up faster, because the cell is more polarized; also, the time required to reach the cutoff potential is shorter for the larger particles. Consequently, the final temperature of a cell with smaller particles is higher than the final temperature of a cell with larger particles because the cell with smaller particles does not reach the cutoff voltage as soon as a cell with larger particles. These results indicate that electrodes with smaller particles are more likely to cause heating of the cell under the conditions described. Another important point is that the cell discharged at the lower current density $\left(12.12 \mathrm{~mA} / \mathrm{cm}^{2}\right)$ reaches a higher temperature than the cell discharged at the higher current density $\left(20.20 \mathrm{~mA} / \mathrm{cm}^{2}\right)$ for a given particle size (compare Fig. 10b to a). Figure $10 \mathrm{~b}$ also shows that the electrode with $15 \mu \mathrm{m}$ of particle size reaches $135^{\circ} \mathrm{C}$, which would cause the separator to melt. Since a melted separator would prevent any diffusion of $\mathrm{Li}^{+}$across the separator, the cell would behave like a batch reactor (because the decomposition reaction of the negative electrode would continue to take place after the separator melts). The equations used in this case and the procedure used to make predictions of the cell temperature are given in Appendix A. 

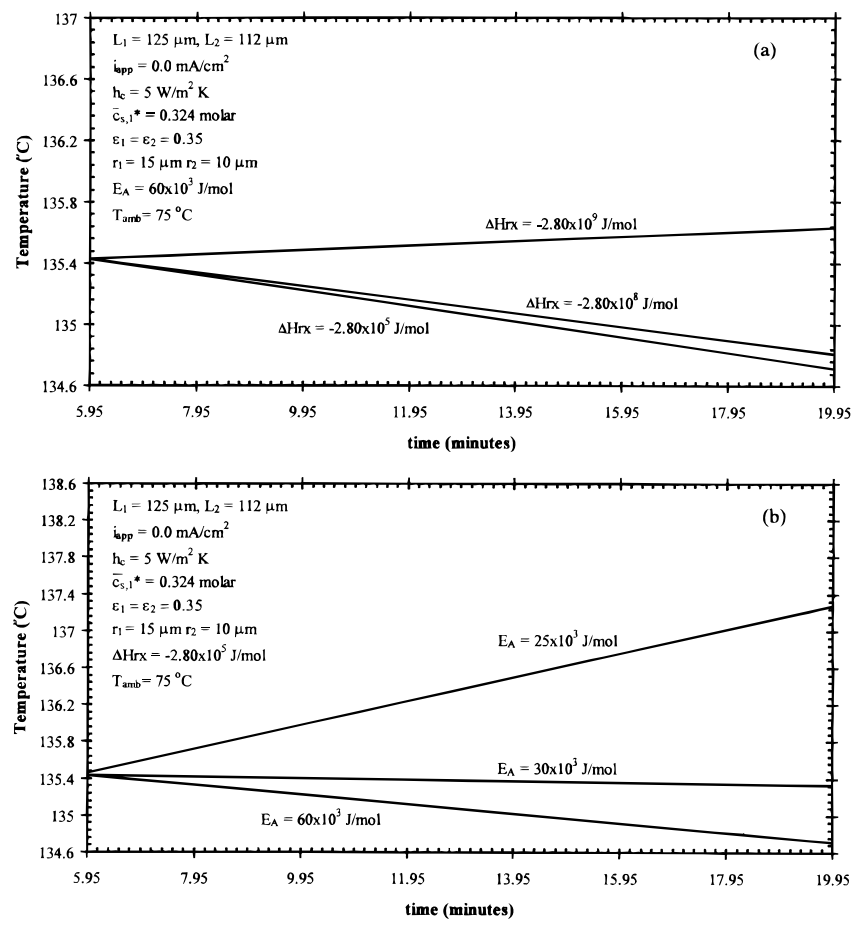

Figure 11. Effect of the parameters of the decomposition reaction of the anode in the temperature of the cell after the separator has melted $(T=$ $135^{\circ} \mathrm{C}$ ). The data presented here has been calculated using Eq. 8 (without the ohmic heat term) and Eq. A-29, the initial input for these equations are the last values obtained from the simulation given in Fig. 10b after the galvanostatic discharge ( $t=5.95 \mathrm{~min})$ for the anode particle radius $r_{1}=15 \mu \mathrm{m}$; (a) effect of the enthalpy of reaction $\left(\Delta H_{\mathrm{rx}}\right)$, and (b) effect of the activation energy $\left(E_{\mathrm{A}}\right)$.

Figure 11 presents the predicted cell temperature for various values of the heat of reaction and activation energy of the decomposition reaction of the carbon anode electrode. Figures 11a and b show that depending on the values of the heat of reaction and the activation energy, different rates of heating of the cell may take place. The predictions presented in Fig. 11 are based on the results given in Fig. $10 \mathrm{~b}$ for the $15 \mu \mathrm{m}$ particle size. As shown in Fig. 10b, the cell was assumed to behave as a batch reactor after $t=5.95 \mathrm{~min}$, and at this time, the last average concentration in the anode is $\bar{c}_{\mathrm{s}, 1}^{*}=$ 0.324 molar (calculated with Eq. A-27). Figure 11 indicates that it is very important to obtain accurate values for the activation energy and the heat of reaction for the decomposition of the negative electrode because for the case when $\Delta H_{\mathrm{rxn}}=-2.8 \times 10^{5} \mathrm{~J} / \mathrm{mol}$ and $E_{\mathrm{A}}=25 \times 10^{3} \mathrm{~J} / \mathrm{mol}$ (see Fig. $11 \mathrm{~b}$ ) the cell could continue to heat up above the melting point of the separator.

\section{Conclusions}

The model predictions presented here indicate that the negative electrode active material particle size (assumed to be spherical) is an important parameter in the heating rate of the cell for high and moderate discharge rates. Larger particles cause higher heating rates due to surface overpotential, and solid-state diffusion limitations. Carbon electrodes made with small particles lead to higher temperatures in the cell, because at high and moderate discharge rates, the total heat generated by the cell with small particles in the negative electrode is larger than that with big particles because it takes longer to reach the cutoff voltage for the cell with smaller particles and the cell continues to heat up during this time.

The contribution of the self-heating of the carbon electrode (due to the decomposition reaction) to the total heat of the cell is negligible compared to the ohmic heat except at relatively high temperatures. The activation energy and the heat of reaction of the anode decomposition play a significant role in the thermal behavior of the cell, therefore very accurate values of these parameters are needed to improve the predictions of the model presented here.

\section{Acknowledgments}

Financial support was provided in part by NSF/EPSCoR IGRT award DGE-9553409. Additional support was provided by the Office of Research and Development, contract 93-F148100-100.

We thank Dr. Zhengming (John) Zhang from Celgard for his valuable comments and the helpful discussions that the authors had with him.

The University of South Carolina assisted in meeting the publication costs of this article.

\section{Appendix A}

Summary of Model Equations

The model includes three regions, as shown in Fig. 1. In the liquid-phase of both electrodes, the equations are ${ }^{27}$

$$
\begin{aligned}
\epsilon_{\mathrm{k}} \frac{\partial c}{\partial t}=\frac{\partial}{\partial z}\left(\epsilon_{\mathrm{k}} D_{\mathrm{eff}, \mathrm{k}} \frac{\partial c}{\partial z}\right)-\frac{i_{2}}{F} \frac{\partial t_{+}^{0}}{\partial z}+a_{3, \mathrm{k}} j_{+\mathrm{n}, \mathrm{k}}\left(1-t_{+}^{0}\right) \\
\mathrm{k}=1,2 \text { (see Fig. 1) [A-1] }
\end{aligned}
$$

where the reaction term due to the decomposition of the anode electrode has been neglected, due to the insignificant change in the concentration caused by this term compared with the diffusion and migration processes in the cell.

The effective diffusion coefficients, $D_{\text {eff.k }}$, are calculated using Bruggeman correction, which leads to ${ }^{27}$

$$
D_{\text {eff, } \mathrm{k}}=\epsilon_{\mathrm{k}}^{1.5} D \quad \mathrm{k}=1,2
$$

where the diffusion coefficient, $D$, is given by Eq. 10 .

The current density in the liquid-phase is given by

$i_{2}=-\kappa_{\mathrm{k}} \frac{\partial \phi_{2}}{\partial z}+\frac{\kappa_{\mathrm{k}} R T}{F}\left(1+\left(\frac{\partial \ln f}{\partial \ln c}\right)\right)\left(1-t_{+}^{0}\right) \frac{\partial \ln c}{\partial z}$

where the potential $\phi_{2}$ has been defined with respect to a lithium reference electrode. For a single electrode reaction such as

$$
\sum_{i} s_{\mathrm{i}} M_{\mathrm{i}}^{\mathrm{z}_{\mathrm{i}}} \rightleftarrows n \mathrm{e}^{-}
$$

The pore-wall flux of $\mathrm{Li}^{+}$across the solid/liquid interface is given by

$$
a_{3, \mathrm{k}} j_{+\mathrm{n}, \mathrm{k}}=\frac{-s_{+}}{n F} \frac{\partial i_{2}}{\partial z} \quad \mathrm{k}=1,2
$$

For a general lithium insertion process, the following form is assumed ${ }^{16}$

$$
\mathrm{Li}^{+}+\mathrm{e}^{-}+\theta_{\mathrm{s}} \rightleftarrows \mathrm{Li}-\theta_{\mathrm{s}}
$$

where $\theta_{\mathrm{s}}$ represents a site in the solid insertion material. From this reaction, $n=1$ and $s_{+}=-1$. Therefore, Eq. A- 5 becomes

$$
a_{3, \mathrm{k}} j_{+\mathrm{n}, \mathrm{k}}=\frac{1}{F} \frac{\partial i_{2}}{\partial z} \quad \mathrm{k}=1,2
$$

The potential in the solid phase of the electrodes is given by ${ }^{16}$

$$
\frac{\partial \phi_{1}}{\partial z}=-\frac{i_{1}}{\sigma_{\mathrm{k}}} \quad \mathrm{k}=1,2
$$

where $i_{1}$ is the current density in the solid phase and is equal to the difference between the applied current density and the current density in solution phase (i.e., $i_{1}=i_{\text {app }}-i_{2}$ ).

The solid diffusion of $\mathrm{Li}^{+}$in the particles of the electrodes is given by (assuming spherical particles)

$$
\frac{\partial c_{\mathrm{s}, \mathrm{k}}}{\partial t}=D_{\mathrm{sk}}\left(\frac{\partial^{2} c_{\mathrm{s}, \mathrm{k}}}{\partial r^{2}}+\frac{2}{r} \frac{\partial c_{\mathrm{s}, \mathrm{k}}}{\partial r}\right) \quad \mathrm{k}=1,2
$$

from symmetry 


$$
\left.\frac{\partial c_{\mathrm{s}, \mathrm{k}}}{\partial t}\right|_{r=0}=0 \quad \mathrm{k}=1,2
$$

The two phases are related with the boundary condition at the surface of the solid-phase particles, where ${ }^{27}$

$$
j_{+\mathrm{n}, \mathrm{k}}=-\left.D_{\mathrm{sk}} \frac{\partial c_{\mathrm{s}, \mathrm{k}}}{\partial r}\right|_{r=r_{\mathrm{k}}} \quad \mathrm{k}=1,2
$$

Since the diffusion coefficients in the solid phase $\left(D_{\mathrm{sk}}\right)$ were taken to be constant Eq. A-9 to A-11 can be solved independently by the method of superposition transforming the pseudo-two-dimensional problem in onedimensional as made by Doyle et al. ${ }^{9}$ The solution of Eq. A-9 to A-11 is given as Eq. 2-74 in Ref. 27.

Furthermore, the pore wall flux, $j_{+\mathrm{n}, \mathrm{k}}$ is represented by the Butler-Volmer form of the electrode kinetics such that

$$
j_{+\mathrm{n}, \mathrm{k}}=\frac{i_{0, \mathrm{k}}}{F}\left[\exp \left(\frac{\alpha_{\mathrm{a}, \mathrm{k}} F \eta_{\mathrm{s}, \mathrm{k}}}{R T}\right)-\exp \left(-\frac{\alpha_{\mathrm{c}, \mathrm{k}} F \eta_{\mathrm{s}, \mathrm{k}}}{R T}\right)\right] \quad \mathrm{k}=1,2
$$

where the exchange current density is given by ${ }^{27}$

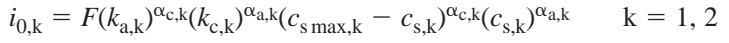

where the overpotential, $\eta_{\mathrm{s}}$ is defined as

$$
\eta_{\mathrm{s}, \mathrm{k}}=\phi_{1}-\phi_{2}-\mathrm{U}_{\mathrm{k}} \quad \mathrm{k}=1,2
$$

For the carbon negative electrode, the open-circuit potential function is given by ${ }^{24}$

$$
U_{1}=-0.16+1.32 \exp (-3 x)
$$

where $x$ is the insertion fraction in $\mathrm{Li}_{x} \mathrm{C}_{6}(0.0<x<0.7)$. For the nickel dioxide positive electrode, the open-circuit potential function ${ }^{17}$

$$
\begin{aligned}
U_{2}=6.515+2.3192 y-5.3342 y^{1 / 2} & +0.41082 \exp [200(0.44-y)] \\
& -0.24247 \exp [60(y-0.99)]
\end{aligned}
$$

was used, where $y$ is the insertion fraction in $\mathrm{Li}_{y} \mathrm{NiO}_{2}(0.45<y<1.0)$. Furthermore, both Eq. A-15 and A-16 provide values for $U_{1}$ and $U_{2}$ in $\mathrm{V}$. The insertion fractions for the anode and the cathode can be calculated through

$$
\begin{aligned}
& x=\frac{c_{\mathrm{s}, 1}}{c_{\mathrm{smax}, 1}} \\
& y=\frac{c_{\mathrm{s}, 2}}{c_{\mathrm{smax}, 2}}
\end{aligned}
$$

In the separator region Eq. A-1 and A-3 apply with $j_{+\mathrm{n}, \mathrm{k}}=0$, the value of the porosity corresponds to the porosity of the separator, $\epsilon_{\mathrm{s}}$, and the effective diffusivity becomes the effective diffusion coefficient of the separator, $D_{\text {eff,s }}$. The initial and boundary conditions used are

$$
\begin{gathered}
c=c_{0} \text { at } t=t_{0}, \forall z \\
\frac{\partial c}{\partial z}=0 \text { at } z=0, \text { and } z=L_{1}+L_{\mathrm{s}}+L_{2}, \forall t>0 \\
i_{2}=0 \text { at } z=0, \text { and } z=L_{1}+L_{\mathrm{s}}+L_{2} \forall t>0 \\
\phi_{2}=0 \text { at } z=L, \forall t>0
\end{gathered}
$$

The equations for the internal interfaces $z=L_{1}$ and $z=L_{1}+L_{\mathrm{S}}$ are

$$
\begin{array}{r}
{\left.\left[D_{\mathrm{eff}, \mathrm{k}} \frac{\partial c}{\partial z}\right]\right|_{z=-\mathrm{L}_{1}}=\left.\left[D_{\mathrm{eff}, \mathrm{k}} \frac{\partial c}{\partial z}\right]\right|_{z=+\mathrm{L}_{1}} \text { at } z=L_{1}, \forall t>0} \\
{\left.\left[D_{\mathrm{eff}, \mathrm{k}} \frac{\partial c}{\partial z}\right]\right|_{z=-\left(\mathrm{L}_{1}+\mathrm{L}_{\mathrm{s}}\right)}} \\
=\left.\left[D_{\mathrm{eff}, \mathrm{k}} \frac{\partial c}{\partial z}\right]\right|_{z=+\left(\mathrm{L}_{1}+\mathrm{L}_{\mathrm{s}}\right)} \text { at } z=L_{1}+L_{\mathrm{s}}, \forall t>0
\end{array}
$$

$$
\begin{gathered}
i_{2}=i_{\text {app }} \text { at } z=L_{1} \text {, and } z=\left(L_{1}+L_{\mathrm{s}}\right) \forall t>0 \\
\frac{\partial \phi_{1}}{\partial z}=0 \text { at } z=L_{1} \text {, and } z=\left(L_{1}+L_{\mathrm{S}}\right) \forall t>0
\end{gathered}
$$

There are two independent variables (i.e., $t$ and $z$ ) and six dependent variables (i.e., $c, \phi_{2}, i_{2}, j_{+\mathrm{n}, \mathrm{k}}, \phi_{1}$, and $c_{\mathrm{s}, \mathrm{k}}$ ). The six independent equations for these variables are A-1, A-3, A-7, A-8, the solution of A-9 to A-11 (given by Doyle ${ }^{27}$ ), and A-12. These equations were discretized by using the CrankNicolson method with three-point finite difference formulas for both the first and second derivatives. The resulting coupled nonlinear algebraic equations were solved by using Newton-Raphson iteration with the BAND $(\mathrm{J})$ algorithm developed by Newman. ${ }^{29}$ For the internal boundary conditions the control volume method was used as discussed in Ref. 27.

After solving these equations, the average concentration of $\mathrm{Li}$ ions at the surface of the carbon particles in the anode was obtained at a given time by

$$
\bar{c}_{\mathrm{s}, 1}^{*}=\frac{1}{L_{1}} \int_{z=0}^{z=L_{1}} c_{\mathrm{s}, 1}^{*} d z
$$

where the lithium concentration at the surface of the particles is obtained by the solution of Eq. A-9 to A-11. ${ }^{27}$ This average concentration was used to evaluate the reaction rate of the anode decomposition, using Eq. 2. Equation 8 was solved to obtain the temperature at the given time, using the initial condition

$$
T=T_{0} \quad \text { at } t=t_{0}, \forall z
$$

It can be noticed that the solution of Eq. 2 and 8 implies an iteration procedure since Eq. 2 also depends on temperature. The procedure explained above is used during the normal charge or discharge of the battery. If the temperature of the cell reaches the melting point of the separator $\left(T=135^{\circ} \mathrm{C}\right)$, the system is modeled in a different way. In this case, the equation for the energy balance is changed by dropping the ohmic heat term (second term on the right of Eq. 8) in Eq. 8; the resultant equation is coupled with the following mass balance in the negative electrode

$$
\frac{d \bar{c}_{\mathrm{s}, 1}^{*}}{d t}=-k_{1} \bar{c}_{\mathrm{s}, 1}^{*} \exp \left(\frac{-E_{\mathrm{A}}}{R T}\right)
$$

It is worth mentioning that a general mass balance in the cell was not performed because the change in the concentration due to the decomposition reaction of the anode was insignificant. The initial condition for Eq. A-29 is given by Eq. A-27 evaluated at the time at which the separator melts. Therefore, after the separator melts, only two equations are used, A-29 and the modified Eq. 8.

\section{Appendix B \\ Cell Parameters and Densities}

The volume of the cell is defined by

$$
v_{\mathrm{c}}=S L
$$

where the projected surface area of the electrodes, $S$, was assumed to be equal to $0.05 \mathrm{~m}^{2}$. The thickness of the cell, $L$, is given by

$$
L=L_{\mathrm{c}, 1}+L_{1}+L_{\mathrm{s}}+L_{2}+L_{\mathrm{c}, 2}
$$

where $L_{\mathrm{c}, 1}$ and $L_{\mathrm{c}, 2}$ represent the thickness of the current collectors in the negative and positive electrodes, respectively. $L_{1}, L_{\mathrm{s}}$, and $L_{2}$ represent the thickness of the negative electrode, separator, and positive electrode, respectively as shown in Fig. 1.

The external surface area of the cell, $S_{\mathrm{e}}$, is given by

$$
S_{\mathrm{e}}=f_{\mathrm{o}}\left(2 \pi r_{\mathrm{c}} h+2 \pi r_{\mathrm{c}}^{2}\right)
$$

where the radius of the 18650 cell and the height are $r_{\mathrm{c}}=9 \mathrm{~mm}$ and $h=$ $65 \mathrm{~mm}$, respectively. The symbol $f_{\mathrm{o}}$ is a conversion factor equal to $1 \times$ $10^{-6} \mathrm{~m}^{2} / \mathrm{mm}^{2}$, therefore $S_{\mathrm{e}}$ is given in $\mathrm{m}^{2}$.

The geometric electrode surface area per volume of the cell, $a_{1}$, is calculated from

$$
a_{1}=\frac{S}{v_{\mathrm{c}}}
$$

The ratio of external cell surface area to geometric electrode surface area, $a_{2}$, is calculated from

$$
a_{2}=\frac{S_{\mathrm{e}}}{S}
$$


The interfacial area of solid-phase particles per unit volume of porous electrode, $a_{3, \mathrm{k}}$, is given by ${ }^{27}$

$$
a_{3, \mathrm{k}}=\frac{3\left(1-\varepsilon_{\mathrm{k}}\right)}{r_{\mathrm{k}}} \quad \mathrm{k}=1,2
$$

The ratio of the solid volume of the anode insertion material to the volume of the cell, $a_{4}$, is

$$
a_{4}=\frac{\left(1-\varepsilon_{1}\right) L_{1}}{L}
$$
by $^{27}$

The maximum concentration of lithium ions in the solid phase is given

$$
c_{\mathrm{s} \max , \mathrm{k}}=f_{1} \frac{\rho_{\mathrm{i}, \mathrm{k}} C_{\mathrm{c}, \mathrm{k}}}{F} \quad k=1,2
$$

where the density of the insertion materials, $\rho_{\mathrm{i}, \mathrm{k}}$, is defined with $x=1$ and $y=1$, for the negative and positive electrode, respectively; and $C_{\mathrm{c}, \mathrm{k}}$ is the theoretical coulombic capacity of the electrode $\mathrm{k}$. The symbol $f_{1}$ is a conversion factor equal to 3600 ( $\mathrm{A} \mathrm{g} \mathrm{s}) /(\mathrm{mA} \mathrm{kg} \mathrm{h})$.

The theoretical coulombic capacities of the electrodes were calculated using Faraday's law, and they were corrected by a factor to account for the range of the insertion fraction of lithium in which the open-circuit potential is given. These theoretical capacities are

$$
C_{\mathrm{c}, \mathrm{k}}=\frac{F}{f_{2} M_{\mathrm{k}}} c_{\mathrm{f}, \mathrm{k}} \quad k=1,2
$$

where $M_{\mathrm{k}}$ is the molecular weight of the electrode insertion material with $x$ $=1$ for the anode and $y=1$ for the cathode, and is given in $\mathrm{g} / \mathrm{mol}$. The electrode capacity correction factor for the cathode was assumed to be $c_{\mathrm{f}, 2}=$ 0.55 . In the anode, the correction factor was assumed to be $c_{\mathrm{f}, 1}=1.0$, in order to evaluate the effect of having the complete capacity of the negative electrode (since its decomposition reaction has been considered in the model) The symbol $f_{2}$ is a conversion factor equal to $3.6(\mathrm{~A} \mathrm{~s}) /(\mathrm{mA} \mathrm{h})$.

The applied current density equivalent to a theoretical $1 \mathrm{C}$ discharge rate was calculated based on the theoretical coulombic capacity of the negative electrode

$$
i_{\text {app }}=C_{\mathrm{c}, 1} \rho_{\mathrm{i}, 1}\left(x_{0}-x_{\mathrm{f}}\right) L_{1} f_{3}
$$

where the density of the negative insertion material, $\rho_{\mathrm{i}, 1}$, is defined with $x=$ 1 , the initial and final intercalation fractions in the negative electrode are equal to $x_{0}=0.5$ (see Table I), and $x_{\mathrm{f}}=0$ (completely discharged), respectively. The symbol $f_{3}$ is a conversion factor equal to $0.1\left(\mathrm{~g} \mathrm{~m}^{2}\right) /\left(\mathrm{kg} \mathrm{cm}^{2}\right)$.

The density of the cell is calculated from

$$
\rho=\frac{\sum_{k=1}^{2}\left[\rho_{\mathrm{c}, \mathrm{k}} L_{\mathrm{c}, \mathrm{k}}\right]+\sum_{k=1}^{2}\left[\rho_{\mathrm{i}, \mathrm{k}}\left(1-\varepsilon_{\mathrm{k}}\right) L_{\mathrm{k}}\right]+L_{\mathrm{s}}\left(1-\varepsilon_{\mathrm{s}}\right) \rho_{\mathrm{s}}}{L}
$$

where $\rho_{c, k}$ and $\rho_{\mathrm{s}}$ represent the density of the current collectors and separator, respectively. The density of the insertion materials, $\rho_{\mathrm{i}, \mathrm{k}}$, is defined with $x=1$ and $y=1$, for the negative and positive electrodes, respectively. The densities of the individual components of the cell are given in Table II.

\section{List of Symbols}

$a_{1} \quad$ geometric electrode surface area per unit volume of cell sandwich, $\mathrm{m}^{2} / \mathrm{m}^{3}$

$a_{2}$ ratio of external cell surface area to geometric electrode surface area, $\mathrm{m}^{2} / \mathrm{m}^{2}$

$a_{3, \mathrm{k}} \quad$ interfacial area of solid-phase particles per unit volume of porous electrode $\mathrm{k}(\mathrm{k}=1,2), \mathrm{m}^{2} / \mathrm{m}^{3}$

$a_{4} \quad$ ratio of the solid volume of the anode insertion material to volume of cell sandwich, $\mathrm{m}^{3} / \mathrm{m}^{3}$

$c \quad$ concentration of electrolyte, $\mathrm{mol} / \mathrm{m}^{3}$

$C_{\mathrm{c}, \mathrm{k}} \quad$ theoretical coulombic capacity of the electrode $\mathrm{k}(\mathrm{k}=1,2), \mathrm{mAh} / \mathrm{g}$

$c_{\mathrm{f}, \mathrm{k}}$ electrode capacity correction factor for the electrode $\mathrm{k}(\mathrm{k}=1,2)$, dimensionless

$c_{0} \quad$ initial concentration of electrolyte, $\mathrm{mol} / \mathrm{m} 3$

$c_{\mathrm{s}, \mathrm{k}} \quad$ concentration of lithium ions in solid-phase in electrode $\mathrm{k}(\mathrm{k}=1,2)$, $\mathrm{mol} / \mathrm{m}^{3}$

$c_{\mathrm{s}, 1}^{*} \quad$ surface concentration of lithium ions in solid-phase of the anode, $\mathrm{mol} / \mathrm{m}^{3}$ $\bar{c}_{\mathrm{s}, 1}^{*} \quad$ average surface concentration of lithium ions in solid phase of the anode, $\mathrm{mol} / \mathrm{m}^{3}$

$c_{\text {smax }, \mathrm{k}}$ maximum concentration of lithium ions in solid phase in electrode $\mathrm{k}$ $(\mathrm{k}=1,2), \mathrm{mol} / \mathrm{m}^{3}$

$C_{\mathrm{p}} \quad$ constant pressure cell heat capacity, $\mathrm{J} / \mathrm{kg} \mathrm{K}$

$D$ diffusion coefficient of electrolyte, $\mathrm{m}^{2} / \mathrm{s}$

$D_{\text {eff,k }}$ effective diffusion coefficient of electrolyte in the electrode $\mathrm{k}(\mathrm{k}=$ 1 , and 2 for the negative and positive electrode, respectively), $\mathrm{m}^{2} / \mathrm{s}$

$D_{\text {eff.s }}$ effective diffusion coefficient of electrolyte in the separator region, $\mathrm{m}^{2} / \mathrm{s}$

$D_{0+}$ diffusion coefficient of cations in the solvent, $\mathrm{m}^{2} / \mathrm{s}$

$D_{0-}$ diffusion coefficient of anions in the solvent, $\mathrm{m}^{2} / \mathrm{s}$

$D_{\text {sk }} \quad$ diffusion coefficient of lithium-ions in solid-phase for electrode k $(\mathrm{k}=1,2), \mathrm{m}^{2} / \mathrm{s}$

$E_{\mathrm{A}} \quad$ activation energy for reaction shown in Eq. 2, J/mol

$f \quad$ activity coefficient of the electrolyte, dimensionless

$f_{\mathrm{o}} \quad$ conversion factor used in Eq. B-3, $1 \times 10^{-6} \mathrm{~m}^{2} / \mathrm{mm}^{2}$

$f_{1}$ conversion factor used in Eq. B-8, $3600(\mathrm{~A} \mathrm{~g} \mathrm{~s}) /(\mathrm{mA} \mathrm{kg} \mathrm{h})$

$f_{2}$ conversion factor used in Eq. B-9, $3.6(\mathrm{~A} \mathrm{~s}) /(\mathrm{mA} \mathrm{h})$

$f_{3}$ conversion factor used in Eq. B-10, $0.1\left(\mathrm{~g} \mathrm{~m}^{2}\right) /\left(\mathrm{kg} \mathrm{cm}^{2}\right)$

$F \quad$ Faraday's constant, 96,487 C/equiv

$h \quad$ height of the battery, $65 \mathrm{~mm}$

$h_{\mathrm{c}} \quad$ heat transfer coefficient based on external cell surface area, $\mathrm{W} / \mathrm{m}^{2} \mathrm{~K}$

I total applied cell current, A

$i_{0, \mathrm{k}} \quad$ exchange current density for the electrode $\mathrm{k}(\mathrm{k}=1,2), \mathrm{A} / \mathrm{m}^{2}$

$i_{1} \quad$ solid-phase current density, $\mathrm{A} / \mathrm{m}^{2}$

$i_{2} \quad$ electrolyte-phase current density, $\mathrm{A} / \mathrm{m}^{2}$

$i_{\text {app }} \quad$ applied cell current per unit of projected electrode area, $\mathrm{A} / \mathrm{m}^{2}$

$i_{\mathrm{n}, \mathrm{k}} \quad$ local interfacial current per unit of solid-phase particle area for electrode $\mathrm{k}(\mathrm{k}=1,2), \mathrm{A} / \mathrm{m}^{2}$

$j_{+\mathrm{n}, \mathrm{k}}$ pore-wall flux of $\mathrm{Li}^{+}$across interface for the electrode $\mathrm{k}(\mathrm{k}=1,2)$, $\mathrm{mol} / \mathrm{m}^{2} \mathrm{~s}$

$k_{1} \quad$ anode decomposition reaction rate constant, $1 / \mathrm{s}$

$k_{\mathrm{a}, \mathrm{k}}$ anodic reaction rate constant for electrode $\mathrm{k}(\mathrm{k}=1,2), \mathrm{m} / \mathrm{s}$

$k_{\mathrm{c}, \mathrm{k}} \quad$ cathodic reaction rate constant for electrode $\mathrm{k}(\mathrm{k}=1,2), \mathrm{m} / \mathrm{s}$

$L$ total thickness of the cell given by Eq. B-2, $\mathrm{m}$

$L_{\mathrm{c}, \mathrm{k}} \quad$ thickness of current collector for electrode $\mathrm{k}(\mathrm{k}=1$ and 2 for negative and positive electrode, respectively), $\mathrm{m}$

$L_{\mathrm{k}} \quad$ thickness of electrode $\mathrm{k}(\mathrm{k}=1,2), \mathrm{m}$

$L_{\mathrm{s}} \quad$ thickness of separator, $\mathrm{m}$

$M_{\mathrm{i}} \quad$ species involved in the general electrode reaction given in Eq. A-4, dimensionless

$M_{\mathrm{k}} \quad$ molecular weight of the active material in electrode $\mathrm{k}(\mathrm{k}=1,2), \mathrm{g} / \mathrm{mol}$

$n \quad$ number of electrons transferred in general electrode reaction given in Eq. A-4, dimensionless ( $n=1$, see Eq. A-6)

$\dot{Q} \quad$ heat-transfer rate from the cell to the environment per volume of the cell, $\mathrm{J} / \mathrm{m}^{3} \mathrm{~s}$

radial coordinate of solid-phase particles, $\mathrm{m}$

$r_{\mathrm{c}} \quad$ radius of the battery, $9 \mathrm{~mm}$

$r_{\mathrm{k}}$ radius of solid-phase particles in electrode $\mathrm{k}(\mathrm{k}=1$ and 2 for negative and positive electrode, respectively), $\mathrm{m}$

$R \quad$ universal gas constant, $8.3143 \mathrm{~J} / \mathrm{mol} \mathrm{K}$

$\Re \quad$ anode decomposition rate of reaction represented in Eq. 2 per volume of the cell, $\mathrm{mol} / \mathrm{m}^{3} \mathrm{~s}$

$S \quad$ geometric area of electrodes, $\mathrm{m}^{2}$

$S_{\mathrm{e}} \quad$ external surface area of the battery, $\mathrm{m}^{2}$

$s_{\mathrm{i}} \quad$ stoichiometric coefficient of species i in the general electrode reaction given in Eq. A-4, dimensionless

$s_{+} \quad$ stoichiometric coefficient of cations involved in the general insertion process given in Eq. A-6, dimensionless $\left(s_{+}=-1\right)$

time, $\mathrm{s}$

initial time, $s$

transference number of species cations, dimensionless

absolute cell temperature, $\mathrm{K}$

$T_{\text {amb }} \quad$ absolute ambient temperature, $\mathrm{K}$

$T_{0} \quad$ absolute initial temperature of the cell, $\mathrm{K}$

$U_{\mathrm{k}} \quad$ open-circuit potential of the electrode $\mathrm{k}(\mathrm{k}=1,2)$ respect to a lithium electrode, ${ }^{14} \mathrm{~V}$

$U_{1} \quad$ anode open-circuit potential respect to a lithium electrode, ${ }^{9} \mathrm{~V}$

$U_{2} \quad$ cathode open-circuit potential respect to a lithium electrode, ${ }^{17} \mathrm{~V}$

$U_{\mathrm{H}, \mathrm{k}} \quad$ local enthalpy potential for the electrode $\mathrm{k}(\mathrm{k}=1,2),{ }^{14} \mathrm{~V}$

$U_{\mathrm{ocp}} \quad$ open circuit potential of the cell, $\mathrm{V}$

$V_{\mathrm{k}} \quad$ volume of electrode $\mathrm{k}(\mathrm{k}=1,2), \mathrm{m}^{3}$

$V \quad$ cell potential, $\mathrm{V}$

$v_{\mathrm{c}} \quad$ volume of the cell, $\mathrm{m}^{3}$

$x \quad$ insertion fraction of lithium in $\mathrm{Li}_{x} \mathrm{C}_{6}$, dimensionless

$y \quad$ insertion fraction of lithium in $\mathrm{Li}_{y} \mathrm{NiO}_{2}$, dimensionless 
$z \quad$ spatial coordinate of cell sandwich, $m$

$z_{\mathrm{i}} \quad$ charge of species $\mathrm{i}$ in the electrode reaction given in Eq. A-4, dimensionless

Greek

$\alpha_{\mathrm{a}, \mathrm{k}} \quad$ anodic transfer coefficient for the electrode $\mathrm{k}(\mathrm{k}=1,2)$, dimensionless

$\alpha_{c} \quad$ cathodic transfer coefficient for the electrode $\mathrm{k}(\mathrm{k}=1,2)$, dimensionless

$\delta \quad$ extent-of-reaction parameter (see Eq. 1), dimensionless

$\Delta H_{\mathrm{rxn}}$ heat of reaction for anode decomposition reaction represented in Eq. $1,-2.89 \times 10^{5} \mathrm{~J} / \mathrm{mol}^{13}$

$\epsilon_{\mathrm{k}}$ porosity of region $\mathrm{k}(\mathrm{k}=1$, and 2 for the negative and positive electrode, respectively), dimensionless

$\epsilon \mathrm{S} \quad$ porosity of separator, dimensionless

$\phi_{1} \quad$ solid-phase potential, V

$\phi_{2} \quad$ electrolyte-phase potential, $\mathrm{V}$

$\eta_{\mathrm{s}, \mathrm{k}} \quad$ overpotential, $\mathrm{V}$

$\mathrm{\kappa}_{\mathrm{k}}$ effective ionic conductivity of electrolyte in the electrode $\mathrm{k}(\mathrm{k}=1$, 2), $\mathrm{S} / \mathrm{m}$

$\kappa_{\mathrm{S}} \quad$ effective ionic conductivity of electrolyte in the separator, $\mathrm{S} / \mathrm{m}$

$\theta_{\mathrm{s}} \quad$ available site in the solid insertion material given in Eq. A-6, dimensionless

$\rho \quad$ cell density, $\mathrm{kg} / \mathrm{m}^{3}$

$\rho_{\mathrm{c}, \mathrm{k}}$ density of current collectors for the electrode $\mathrm{k}(\mathrm{k}=1,2), \mathrm{kg} / \mathrm{m}^{3}$

$\rho_{\mathrm{i}, \mathrm{k}} \quad$ density of insertion material for the electrode $\mathrm{k}(\mathrm{k}=1,2), \mathrm{kg} / \mathrm{m}^{3}$

$\rho_{\mathrm{s}} \quad$ density of separator, $\mathrm{kg} / \mathrm{m}^{3}$

$\sigma_{\mathrm{k}} \quad$ electronic conductivity of solid-phase matrix for electrode $\mathrm{k}(\mathrm{k}=$ $1,2), \mathrm{S} / \mathrm{m}$

Subscripts

$+\quad$ cation

- anion

$0 \quad$ initial condition

1 solid-phase or negative electrode

2 electrolyte-phase or positive electrode

$\mathrm{f}$ final condition

$\mathrm{k}$ given electrode, 1 , and 2 for the negative and positive electrode, respectively solid-phase or separator

\section{References}

1. Moli Energy's New Product Data Sheet, JEC Batt. Newsletter, No. 6, p. 15 (NovDec 1988).

2. No author, Macworld, 12, 36 (1995).

3. No author, Los Angeles Times, p. 1D (Sept 15, 1995).

4. No author, Dagens Industri, p. 10 (Jan 12, 1996).

5. T. I. Evans and R. E. White, J. Electrochem. Soc., 136, 2145 (1989).

6. Y. Chen and J. W. Evans, J. Electrochem. Soc., 143, 2708 (1996).

7. M. W. Verbrugge, AIChE J., 41, 1550 (1995).

8. C. R. Pals and J. Newman, J. Electrochem. Soc., 142, 3274 (1995).

9. M. Doyle, T. F. Fuller, and J. Newman, J. Electrochem. Soc., 140, 1526 (1993).

10. M. A. Gee and F. C. Laman, J. Electrochem. Soc., 140, L53 (1993).

11. J. R. Dahn, E. W. Fuller, M. Obrovac, and U. von Sacken, Solid State Ionics, 69, 265 (1994).

12. U. von Sacken, E. Nodwell, A. Sundher, and J. R. Dahn, Solid State Ionics, 69, 284 (1994).

13. J. Dahn, Personal communication, Fall 1998

14. L. Rao and J. Newman, J. Electrochem. Soc., 144, 2697 (1997).

15. D. Bernardi, E. Pawlikowski, and J. Newman, J. Electrochem. Soc., 132, 5 (1985).

16. T. F. Fuller, M. Doyle, and J. Newman, J. Electrochem. Soc., 141, 1 (1994).

17. J. R. Dahn, U. von Sacken, M. W. Juzkow, and H. Al-Janaby, J. Electrochem. Soc., 138, 2207 (1991)

18. Z. Zhang, D. Douchard, and J. R. Read, J. Power Sources, 70/1, 16 (1998).

19. B. A. Johnson and R. E. White, J. Power Sources, 70/1, 48 (1998).

20. J. Soetens, C. Millot, and B. Maigret, J. Phys. Chem. A, 102/7, 1055 (1998).

21. J. Sullivan, D. Hanson, and R. Keller, J. Electrochem. Soc., 117, 779 (1970)

22. J. Newman, D. Bennion, and C. W. Tobias, Ber. Bunsenges., 7, 608 (1965).

23. P. Yu, B. Popov, J. Ritter, and R. E. White, J. Electrochem. Soc., 146, 8 (1999).

24. M. Doyle, J. Newman, A. S. Gozdz, C. N. Schmutz, and J. Tarascon, J. Electrochem. Soc., 143, 1890 (1996).

25. S. Basu and W. Worrel, Fast Ion Transport In Solids, p. 151, Elsevier-North Holland Inc., New York (1979).

26. P. G. Bruce, A. Lisowska-Oleksiak, M. Y. Saidi, and C. A. Vincent, Solid State Ionics, 57, 353 (1992).

27. C. M. Doyle, Design and Simulation of Lithium Rechargeable Batteries, Ph.D. Thesis, University of California-Berkeley (1995).

28. G. S. Nagarajan, J. W. Van Zee, and R. M. Spotnitz, J. Electrochem. Soc., 145, 771 (1998).

29. J. S. Newman, Electrochemical Systems, pp. 539-555, Prentice-Hall, Inc. Englewood Cliffs, NJ (1991).

30. R. H. Perry and D. W Green, Perry's Chemical Engineering Handbook, McGrawHill, Singapore (1984) 